\title{
SCOPE OF DESIGN FOR PRODUCTION OF PARTITION WALLS AND FACADE COVERINGS
}

\author{
KAREN MANESCHI \\ Arch., Master Candidate, Escola Politécnica - USP, Construction Engineering Department \\ University of São Paulo \\ São Paulo - SP - Brazil. \\ kmaneschi@terra.com.br
}

\section{SILVIO MELHADO}

Associate Professor, Escola Politécnica - USP, Construction Engineering Department University of São Paulo

São Paulo - SP - Brazil.

silvio.melhado@poli.usp.br

\begin{abstract}
In Brazil, the creation and insertion of design for production of partition walls and coverings into the processes of the construction companies have generated significant improvements in the development and rationalization of construction process, providing performance improvements and competitive advantages to these companies.

The design of those constructive elements, besides offering excellent information support for the design management to take strategic decisions, also generates important data to the production team, becoming, therefore, an essential tool for achieving compatibility and buildability in building construction.

Some researches had demonstrated the relevance of design for production in the construction industry; however, the definition of the design contents has not received enough attention from academics and professionals.

In this context, this paper presents the results of a research with a commission of design professionals that aims to establish a Brazilian scope pattern for developing design for production of partition walls and coverings, as a reference to professionals, thus meeting the actual sectorial needs.
\end{abstract}

Keywords: building construction, design scope, design for production, partition walls, masonry, covering.

\section{INTRODUCTION}

The fierce competition between construction companies in the Brazilian market due to the demand for housing and the opening of capital in the private sector provide an increase in searching for rationalized constructions, forwarding the quest for a competitive differential.

There has been an increased demand for design for production, being used as a tool for optimizing and rationalizing construction, due to the inherent design interface between partition walls and coverings, structure, building services and all the other subsystems.

However, this specialty of design has not been fully explored, as the client, for the most part, ignores the right time for recruiting these designers as well as its potential to bring improvements to the constructive process. 
Several are the difficulties between clients and design professionals, either technical or commercial; the difficulties become exacerbated in Brazil by the lack of standards and regulations that can effectively lead those relationships.

The lack of reference for a technical scope of design services, as well as the lack of definition of the design contents delivered by the professionals, generates a distortion in hiring, stimulating competition by pricing without a clear relationship of the design price and its quality. This scenario leads to conflicts between design clients and designers during the process, in addition to allowing losses to the construction process and to the quality in real estate projects.

In this sense, the proposal for elaborating the scope of design for producing partition walls and coverings is paramount, in order to meet the latent need to guide their hiring, and establish the required content of this design and place them in development stages of the design process.

\section{METHODOLOGY}

The research derived from a theoretical study, involving the main references found on the subject, from journals proceedings and books, to theses and reports about this subject, which can add relevant information to the development of the research.

At a second stage, an invitation was sent to a group of professionals working in the area of design for production of partition walls and facade coverings, thus forming a commission based on representative and relevant actuation in the building industry. This group of professionals selected participated in fortnightly meetings, in which the design process was discussed as well as the required content for each stage of development aimed to meet the production team.

The methodology adopted in this study includes action-research and other methods, listed further on, which are widely disseminated in social sciences, tailoring the purpose of this research. Under the terms of their qualitative research, Oliveira (2005) defines the research methodology in his doctoral thesis, pointing out that " in this type of research, there is a contrast to the experimental model as a unique standard to research for all sciences. There is a dynamic relationship between the real world and the subject, an interdependence between the objective world that wants to know and the researcher's subjectivity. "

The same author also quotes Chizzotti (1991) "knowledge is not reduced to an amount of isolated data, connected by an explanatory theory, the subject-observer is a part of the process of knowledge and interprets the phenomena, giving them a meaning". The object is not an inert and neutral data; it possesses meanings and relationships that create concrete subjects in their actions.

According to Alves (1991), there are several qualitative research methods, from which one can mention:

a) case study;

b) life history;

c) ethnographic-anthropological research, participant research;

d) action-research;

e) phenomenological approaches.

According to Thiollent (2004) "Action-research is a kind of social research that is based on empirical design and carried out in close association with an action or with a resolution of a collective problem, in which the researchers and representative participants of the situation or problem are involved in a cooperative or participatory mode”. 
The action-research methodology is indicated when there is collective interest in the solution of a problem or in meeting a need, actively or cooperatively involving the researchers and the participants in the research.

Thiollent (2004) points out that "with action-research, the researchers play an active role in the actual reality of the observed facts".

With action-research, this study was intended as an "action" from both researchers and the group involved in the research, providing an active performance in the resolution of the problems faced.

After finishing the action-research, case studies will be carried out in order to examine the applicability of the proposed scope into the routine of design offices.

As written by Yin (2001), a case study is "an empirical research that investigates a contemporary phenomenon within its context in real life, especially when the boundaries between the phenomenon and the context are not clearly defined".

According to Gil (1989), the case study is characterized by a deep and thorough analysis of one or a few objectives, so as to allow its extensive knowledge, and the benefits of its application are the stimulus to new discoveries and emphasis on the completeness and simplicity of procedures.

The case studies in this research work will serve as data collection, verification of the reality of processes and procedures faced with the scope developed within the design professionals commission.

\section{THE DESIGN OF PARTITION WALLS AND FACADE COVERING}

As stated by Melhado \& Violani (1992), "in order to achieve success in real estate projects, the design can not be restricted to the geometric characterization role of the construction being built. The design must conceive, in addition to the product, its production process; (...) must assume the fundamental role of adding efficiency and quality to the product”.

Sabbatini (1989) also emphasizes the importance of the development of the design for producing the building in which, "(...) constructive techniques are defined (and also the methods if the purpose of development is a constructive process or a system) and the execution details are designed (...) that will allow the construction of the building or its parts in accordance with the general concept".

The design for producing partition walls and facade coverings is a constructive design, which aims to incorporate processes and construction methods in the building conception. Due to its proximity to the constructive processes and its interface with several other subsystems, such as the structure, hydraulic and electrical subsystems, this design has an extraordinary value in the execution of a building.

The design for producing covering facades, as well as partition walls specifically interferes with the rationalization of the building as a whole. According to Barros (1998), the subsystem of partition walls corresponds to $3 \%$ to $6 \%$ of the building cost as a whole. Also considering the interface with other subsystems, this cost excels $20 \%$ of the total building cost. In the subsystem of partition walls, the highest rates of wastage of materials and manual work can be observed, and also the highest rates of pathologies, which are minimized with the development of these designs.

Although there are local particularities concerning constructive processes and methods, the contents of these designs also vary as each designer and not being stipulated as denominator for the development of these designs, so that they can effectively meet the needs of real estate developers. 


\section{THE DESIGN SCOPE OF PARTITION WALLS AND FACADE COVERING}

Melhado (1994), observing the difficulties to the quality improvement of the design process in the segment of real estate and building construction, identifies the problem of the design content vagueness, aiming at better defining the design tasks to be developed in each phase of the design process. Therefore, the author proposes a "design morphology" of residential and commercial building designs. At that time, the proposal was used in some isolated cases; however, this proposition did not lead to a broader discussion in the sector.

A few years later, a working commission of structure designers affiliated to the Brazilian Association of Structural Engineering and Consulting - ABECE started acting, establishing a proposal for the scope of this specialty, in order to accommodate the typical needs of real estate projects. The scope was then discussed in Sao Paulo with representatives of other associations, involving both designers and design clients representatives: AsBEA (Brazilian Association of Architectural Design Offices); ABRASIP (Brazilian Association of Systems Engineering); SindusCon-SP (Construction Industry Union of the State of São Paulo); SECOVI-SP (Real Estate Developers Union - São Paulo). The contributions generated a consensual version of the scope of this design being approved by all other representatives of the aforementioned associations.

In the same view and in analogous way, the scope drafting for design and services of: hydraulic and electrical systems, architecture and urbanism, design coordination, landscaping, air conditioning and mechanical ventilation, building security and automation and sports and leisure facilities were started.

With the conclusion of the work and imminent need in the market in the mid of November 2006, under the leadership of the Polytechnic School of USP, the creation of an expert commission was proposed to lead the development of the scope of the design for production of partition walls and facade coverings. The activities of this commission began in March 2007 and finished in March 2008.

\section{The design process phases and the actuation of the design for production of partition walls and facade coverings}

Based on the other scopes already developed, the design process of real estate projects was subdivided into six phases: Product conception, Product Definition; identification and solution of Interfaces; Design Detailing, Design Post Delivery ; Building Post Delivery .

In each one of these phases, the tasks to be performed by the design professional were listed for producing partition walls and facades covering, and divided into three categories:

- Essential services: tasks that are necessarily performed for the success of the activity, at the corresponding stage of the design process;

- Specific services: tasks that can be contracted, as they are necessary in specific cases, according to the particularities of construction or client specific requirements;

- Optional services: tasks that can eventually, if demanded by the client, be implemented by the designer of partition walls and facade coverings.

The designer actuation for producing partition walls and facade covering in the design phases are as follows:

- Phase A - Product Conception: Supporting the real estate developer in tasks relating to briefing and definition of the data set, collecting the performance requirements for partition walls and facade covering, as well as technological alternatives, and the adoption of modular coordination. 
- Phase B - Product Definition: Define technical solutions for partition walls and facade covering, a critical analysis of the existing procedures for implementing and verifying the design of other specialties at this design stage.

- Phase C - Identification and Solution of Design Interfaces: define the dimensional parameters for the design elaboration as well as the performance requirements of materials and components, analyze and verify the other specialties designs and their interfaces with partition walls and facade covering

- Phase D - Design Detailing: Developing detailing of all elements of design

- Phase E - Post-Delivery of Design: Presenting the designs in order to prepare the production team for the execution of the construction. Support technical tests of facade covering

- Phase F - Building Post-Occupancy: Evaluate and conduct feedback of the design process

\section{GENERAL DESCRIPTION OF DESIGN PHASES AND TASKS}

This item presents the general structure of tasks, phase to phase, constituting the Scope of services for design for production of partition walls and coverings in real estate development projects.

\section{Phase A - Product Conception}

Essential Services:

A001 - Support to the real estate project conceptualization

\begin{tabular}{|l|}
\hline Phase B - Definition of the Product \\
\hline Essential Services: \\
\hline B001 - Collection of performance requirements for partition walls and coverings \\
\hline B002 - Presentation of technological alternatives \\
\hline B003 - Definition of horizontal and vertical dimensional coordination \\
\hline B004 - Definition of technical solution for partition walls and internal and external coverings \\
\hline B005 - Review of existent construction procedures for partition walls and coverings \\
\hline B006 - Preliminary checking of the other specialties designs \\
\hline Specific Services: \\
\hline B101 - Definition of constructive methods for partition walls and coverings \\
\hline Optional Services: \\
\hline B201 - Cross checking of the standard storey plan \\
\hline B202 - Vertical cross checking of construction plans \\
\hline
\end{tabular}




\begin{tabular}{|l|}
\hline Phase C - identification and solution of Design Interfaces \\
\hline Essential Services: \\
\hline C001 - Definition of dimensional parameters for partition walls and coverings \\
\hline $\begin{array}{l}\text { C002 - Identification of the incompatibilities between designs for production of partition } \\
\text { walls and coverings and other specialties designs }\end{array}$ \\
\hline C003 - Consolidated checking of other specialties designs \\
\hline C004 - Dimensional adjustment - horizontal and vertical \\
\hline C005 - Consolidated plan of construction concepts \\
\hline C006 - Definition of performance requirements of materials and components \\
\hline C007 - Validation of coordinates axis \\
\hline Specific Services: \\
\hline C101 - Guidelines for construction methods \\
\hline C102 - Review of non-standard units plans \\
\hline Optional Services: \\
\hline C201 - Technical visit to the full-scale unit in the sales stand \\
\hline C202 - Checking of promotional material \\
\hline C203 - Cross checking of the standard storey plan \\
\hline
\end{tabular}

\begin{tabular}{|l|}
\hline Phase D - Design Detailing \\
\hline Essential Services: \\
\hline D001 - Consolidated verification of other specialties designs \\
\hline D002 - $1^{\text {st }}$ line masonry plan or prefabricated components location plan for standard storeys \\
\hline D003 - Location plan of hydraulic and electrical systems for standard storeys \\
\hline D004 - Detailed view of walls for standard storeys \\
\hline D005 - Quantification of components for standard storeys \\
\hline D006 - Reinforcements and movement joints for standard storey walls \\
\hline D007 - Façade plans \\
\hline D008 - Step by step procedures of façade covering \\
\hline D009 - Definition of the test plan of façade covering \\
\hline
\end{tabular}




\begin{tabular}{|l|}
\hline D010 - Complementary constructive detailing for standard storeys \\
\hline Specific Services: \\
\hline D101 - Checking of structural plans \\
\hline D102 - Quantification of partition walls and coverings surfaces \\
\hline D103 - Production procedures of complementary components for partition walls and covering \\
\hline D104 - Production procedures of partition walls and coverings \\
\hline D105- Design for production of partition walls - non-standard storeys \\
\hline D106- Quantification of materials and components for covering \\
\hline Optional Services: \\
\hline D201 - Production procedure of the on site pre-cast components \\
\hline D202 - Partition walls and covering design for non-standard units \\
\hline D203 - Second-line plans of masonry walls \\
\hline D204 - Internal covering design \\
\hline D205 - Detailing of covering production procedures \\
\hline D206 - Cross checking of the detailed standard storey plan \\
\hline D207 - Cross checking of the façade elements \\
\hline
\end{tabular}

\begin{tabular}{|l|}
\hline Phase E- Design Post-Delivery \\
\hline Essential Services: \\
\hline E001 - Design presentation for the production team - partition walls \\
\hline E002 - Technical visit for the construction preparation for partition walls \\
\hline E003 - Design presentation for the production team - coverings \\
\hline E004 - Technical visit for the construction preparation for coverings \\
\hline E005 - Technical support to façade covering tests \\
\hline Specific Services: \\
\hline E101 - Construction team training \\
\hline E102 - Visit to the prototype unit - partition walls \\
\hline Optional Services: \\
\hline
\end{tabular}


E201 - Elaboration of the owner's manual - partition walls and coverings

\section{Phase F- Building Post-Occupancy}

Essential Services:

F001 - Evaluation and validation of the design process

\section{CONCLUSION}

The design stage is essential for the good development and construction of a building. It is at this stage, preceding the execution, that solutions are designed and developed in high-level discussion. When a design is well elaborated, broaches and foresees issues, it helps buildability, promotes rationalization and therefore the high performance of the construction processes.

By setting up the design scope according to each phase of development, it aims to specify the essential, specific and optional tasks for the particular subsystem under study, giving the designer the main good practice guidelines to be adopted.

For the characteristics inherent in designs for production as a tool for rationalization and optimization in the construction, it is believed that this work of design scope for producing partition walls and façade coverings will provide a better organization among designers as well as clients that will enhance the potential of this type of design.

Currently, the research with the designers commission was finalized and this first version of the design scope was discussed, from April until mid August, 2008 at SECOVI-SP, along with representatives of other entities, designers and design clients.

In this round of meetings, the challenge of converging all considerations into a single document emerged so that it can be converted into a design scope manual that will be available in the web for free to all those interested in the subject.

This research also aims at analysing the implementation of this design scope in the design firms in order to verify its efficiency and effectiveness, and then recommending possible adjustments to the text. This stage of the research will greatly contribute not only to the design practices and methods, but also to design market evolution, since that it will help design clients in the hiring procedure.

\section{REFERENCES}

BARROS, M.M.B. Metodologia para implantação de tecnologias construtivas racionalizadas na produção de edifícios. (Methodology for rationalized construction technologies in the production of buildings). 1996. 254p. Tese (Doutorado) - Escola Politécnica, Universidade de São Paulo. São Paulo, 1996.

BARROS, M.M.B. O processo de produção das alvenarias racionalizadas. (The production process of rationalized masonry). IN: SEMINÁRIO VEDAÇÕES VERTICAIS, 1., São Paulo, 1998. Anais. São Paulo: EPUSP, 1998. p.21-39. 
DUEÑAS PEÑA, M. Método para elaboração de projetos para produção de vedações verticais em alvenaria (Method for the elaboration of design for production of partition walls). 160p. Dissertação (Mestrado) - Escola Politécnica, Universidade de São Paulo. São Paulo, 2003.

FABRICIO, M.M. Projeto simultâneo na construção de edifícios. (Concurrent design in the building construction industry). São Paulo: 2002. Tese (Doutorado) - Escola Politécnica, Universidade de São Paulo.

FRANCO, L.S. Aplicação de diretrizes de racionalização construtiva para a evolução tecnológica dos processos construtivos em alvenaria estrutural não armada. (Implementation of guidelines for rationalization of construction for the development of technological processes in nonreinforced structural masonry) 319p. Tese (Doutorado) - Escola Politécnica, Universidade de São Paulo, São Paulo, 1992.

FRANCO, L.S. O projeto das vedações verticais: características e importância para a racionalização do processo de produção. (The design of partition walls: characteristics and importance to the rationalization of the production process). IN: SEMINÁRIO VEDAÇÕES VERTICAIS, 1., São Paulo, 1998. Anais. São Paulo: EPUSP, 1998. p221-236.

MELHADO, S.B. Qualidade do projeto na construção de edifícios: aplicação ao caso das empresas de incorporação e construção. (Design quality in the building construction: application to the case of real estate and construction companies). 294p. Tese (Doutorado) - Escola Politécnica, Universidade de São Paulo, São Paulo, 1994.

MELHADO, S.B.; BARROS, M.S.B.; SOUZA, A.L.R. Diretrizes para elaboração do projeto de alvenaria de vedação. (Guidelines to the design of partition walls). São Paulo: EPUSP, 1995. (Relatório final)

MELHADO, S.B. Metodologia de projeto voltada à qualidade na construção de edifícios. (Design methodology to achieve building construction quality). In: ENCONTRO NACIONAL DE TECNOLOGIA DO AMBIENTE CONSTRUÍDO: QUALIDADE NO PROCESSO CONSTRUTIVO, 7., Florianópolis, 1998. Anais. Santa Catarina: 1998. p.739- 747

MELHADO, S.B. Gestão, cooperação e integração para um novo modelo voltado à qualidade do processo de projeto na construção de edifícios. (Management, cooperation and integration to a new model dedicated to the quality of the design process in the building construction). $235 \mathrm{p}$. Tese (Livre Docência ) - Escola Politécnica, Universidade de São Paulo. São Paulo, 2001.

MELHADO, S.B.; VIOLANI, M.A.F. Qualidade na construção civil e o projeto de edifícios. (Quality in construction and design of buildings). São Paulo: EPUSP, 1992. (Texto Técnico da Escola Politécnica da USP, Departamento de Engenharia de Construção Civil, TT/PCC/02).

MELHADO, S.B; ADESSE, E.; BUNEMER, R; LEVY, M.C; LOPES, C.; LUONGO, M; MANSO, M.A. Escopo de serviços para coordenação de projetos. (Service scope for design management). Workshop Brasileiro de Gestão do Processo de Projeto na Construção de Edifícios, 2004

OLIVEIRA, O. J.; Modelo de gestão para pequenas empresas de projeto de edifícios. (Management model for small design firms). Tese (Doutorado) - Escola Politécnica, Universidade de São Paulo, São Paulo, 2005 
SABBATINI, F.H. Desenvolvimento de métodos, processos e sistemas construtivos. (Development of methods, process and constructive systems). 1989. Tese (Doutorado) Escola Politécnica, Universidade de São Paulo. São Paulo, 1989.

SABBATINI, F.H. A industrialização e o processo de produção de vedações: utopia ou elemento de competitividade empresarial? (Industrialization and the partition walls production process: utopia or element of competitiveness?). In: I SEMINÁRIO TECNOLOGIA E GESTÃOO NA PRODUÇÃO DE EDIFÍCIOS: Vedações Verticais - São Paulo, 1998. Anais. EPEUSP/PCC, 1998.

THIOLLENT, M. Metodologia da pesquisa-ação. (Methodology of Action- research) 5. ed. São Paulo: Cortez, 2004.

TZORTZOPOULOS, P. Contribuições para o desenvolvimento de um modelo do processo de projeto de edificações em empresas construtoras e incorporadoras de pequeno porte. (Contributions to the development of building design process model in small real estate and construction companies). Dissertação (Mestrado) - Universidade Federal do Rio Grande do Sul. Porto Alegre, 1999.

YIN, Robert K. Estudo de caso: planejamento e método. (Case study: planning and methods) Editora Bookman. $3^{\circ}$ edição, 2001, 212p 